This Section of Epidemiology and Psychiatric Sciences appears in each issue of the Journal and is dedicated to all forms of creative production born of an intimate and individual urge, often secretive, unbound from the conventional art system rules. Through short descriptions of the Outsider art work of prominent artists and new protagonists often hosted in community mental health services, this section intends to investigate the latest developments of the contemporary art scene, where the distances between the edge and the center are becoming more and more vague.

Carole Tansella, Section Editor

\title{
Marcel Storr: a new case of clandestine outsider art
}

\section{Danchin}

Adivisory board member of the Collection de I 'Art Burt (Lausanne), French editor of Raw Vision, (London)

Received 7 January 2015; Accepted 20 January 2015

Key words: Art brut, Marcel storr, Outsider art, Art brut, Retrofuturism.
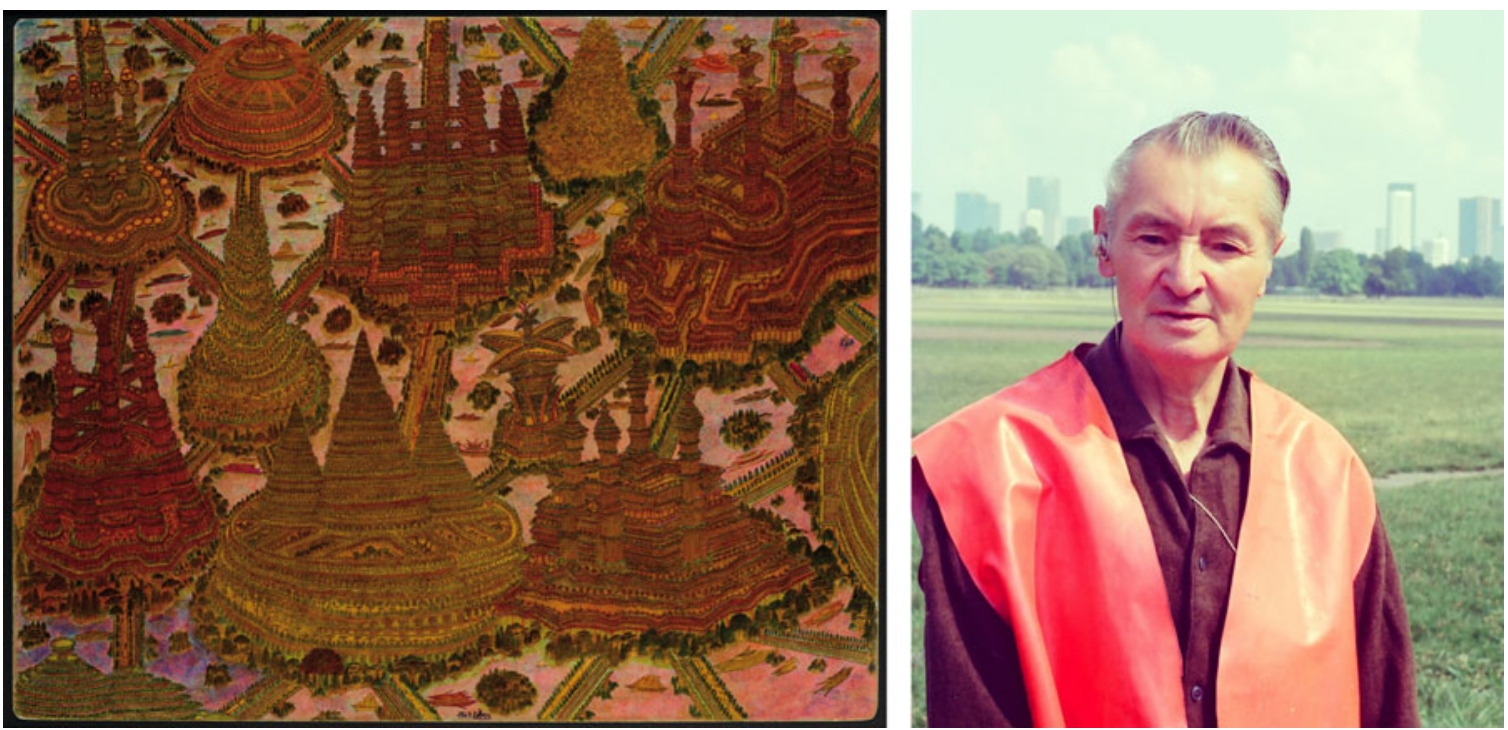

On the left: Marcel Storr, Untitled, Series of the Megalopolises, pencil, ink and varnish on paper, (1969), $50 \times 60 \mathrm{~cm}$, coll B \& L. Kempf.

On the right: Photo of the author.

When I curated the only show of his entire production a few years ago in Paris ${ }^{1}$, Marcel Storr (1911-1976), a street-sweeper in the Bois de Boulogne, and an extraordinary self-taught draughtsman who worked secretly at home, was completely unknown to the art market and at that time his amazing works had no commercial

\footnotetext{
${ }^{1}$ Marcel Storr, bâtisseur visionnaire, Paris, Pavillon Carré de Baudouin, December 15 2011-March 31, 2012.
}

value. Less than 3 years later, after complementary shows in London and New York, ${ }^{2}$ a small drawing of a church was sold for US\$ 80000 and a cityscape of a bigger format for approximately US\$ 175000 . An inflation of such rapidity does not simply illustrate

\footnotetext{
${ }^{2}$ The Alternative Guide to the Universe, London, Hayward Gallery, June 11-August 26, 2013. Marcel Storr: Reimagining Paris, Andrew Edlin Gallery, September 13-October 25, 2014, New York.
} 
the rarity and value of Storr's work, but it also highlights the astonishing craze that has invaded the realm of art brut or outsider art in Europe and America over the last few years (Azimi, 2014).

Born in Paris shortly before WWI, Storr suffered a Dickens-like childhood: at the age of three he was abandoned and sent to work on farms, where he became nearly deaf from the beatings he received. He was then taken care of by nuns in South-western France for a short time, and finally settled in Paris, where he was able to survive by doing various odd-jobs until 1964, when he was given his first regular employment and when he married. Not much is known about his poor early life. We know only that he rarely attended school, that he always loved to draw and had a foster brother who became an architect, and that his first attempts at art-making began in the 1930s (Cloarec, 2010).

In his parallel existence, Storr, who loathed the countryside and preferred large cities, subways, skyscrapers, etc., drew exclusively gigantic, fantasy architectures of a paranoid nature: churches, steeples, towers, palatial cathedrals and basilicas, or retrofuturistic megalopolises menaced by a nuclear war. From this imaginary world, only 63 big coloured drawings remain, owned by Mr. \& Mrs Kempf, the French collectors who discovered the work quite by chance in 1971. In his first series of churches, Storr used only crayons and, to begin with, his style was naïve yet realistic. Then, in a second period, after WWII, he tried gouache, ballpoint and China ink on large pieces of cardboard assembled in huge diptychs or triptychs. But he eventually discovered his style in his last two series of 25 Cathedrals (1964-1965) and 20 Megalopolises (1965-1975), all drawn in two large spiral copy books and where, still using a sharp black pencil, he now coloured his constructions with transparent inks of various hues, and then covered them with a thin layer of varnish (Danchin, 2001).

Outsider art or art brut creators are supposed to be compulsive and stereotyped and not display too much evolution in their style (Danchin, 2006). This is not the case with Marcel Storr, who shows remarkable progress in his art and who gradually reinvents perspective while trying to depict the immensity of the architectures and urbanistic landscapes he has in his mind. To begin with, in his early work, he uses only a frontal view and his big churches are like a flat façade leaning on the void. Then parts of the constructions begin to emerge like on a relief and in order to enhance the effect of gigantism, low-angle shots are spontaneously used. In the series of Cathedrals, Storr continues to adopt the frontal view, but this time to show the profile of the buildings while the façades, like in children's drawings or according to a kind of involuntary cubism, are now warped on the left.
And then, when he is halfway into his series of megalopolises, he suddenly leaves the ground and adopts the aerial view which definitely gives him the opportunity to clearly distinguish the fore- and backgrounds of his compositions and to induce a new sense of infinity. Surrounded by water and trees, elevated highways and suspended trains, the utopian towers of Storr's final landscapes are a rather clumsy yet lyrical hymn to colour and freedom, expressing an urgent need to leave this earth like a series of rockets ready for the sky (Danchin, 2013).

Obsessively inspired and self-taught, but having developed his own skills by a painstaking and ceaseless practice, Marcel Storr is a paradigmatic instance of the outsider or art brut creator. It was only towards the end of his life, sometime after his wife's death, that he suffered from mental disorders and was institutionalised for a short time for a bout of paranoia in 1974, and then treated as an out-patient until his eventual death from cancer, at the age of 65 . Not crazy but different to others, he was an untrained genius and he knew it, and his permanent fear of a nuclear apocalypse is no worse than the phantasms of many authors of his time (Danchin, 2011).

\section{Acknowledgements}

The author thanks Liliane and Bertrand Kempf.

\section{Financial Support}

This research received no specific grant from any funding agency, commercial or not-for-profit sectors.

\section{Conflict of Interest}

None.

\section{References}

Azimi R (2014). La folie de l'art brut. Séguier: Paris.

Cloarec F (2010). Marcel Storr, architecte de l'ailleurs. Phebus: Paris.

Danchin L (2001). The revenge of an underground imagination. Laurent Danchin explores the paranoiac cities and basilicas of Marcel Storr. In Raw Vision, no 36 (ed. J Maizels), pp. 48-53. London.

Danchin L (2006). Art Brut - L'instinct créateur. Gallimard: Paris.

Danchin L (2011). Marcel Storr Le génie à l'état brut. In (eds. F Cloarec, L Danchin, B \& L Kempf), Phebus: Paris.

Danchin L (2013). Marcel Storr, visions d'un monde flottant. In Danchin L, Aux frontières de l'art brut - Un parcours dans l'art des marges, pp. 559-565. Lelivredart: Paris. 


\section{About the Author}

Curator, art critic and writer, a former teacher of French literature and ex alumnus of the Ecole Normale Supérieure (rue d'Ulm, Paris), Laurent Danchin is member of the Board of the Collection de l'Art Brut in Lausanne and the French editor of Raw Vision.

Danchin is a leading authority on Art Brut. His research questioning the ethical and aesthetical developments of this art field provide unique responses to the ongoing debate on the identity of Outsider Art.

$\mathrm{He}$ has curated several exhibitions at the Halle Saint-Pierre in Paris, including Chomo - The spiritual Disembarkment in 2009. His 3-month Parisian exhibition Marcel Storr, bâtisseur visionnaire at the Pavillon Carré de Baudouin in 2011-2012 attracted more than 22000 visitors and had enthusiastic media coverage. With his friend Jean-Luc Giraud, computer artist and draughtsman, he runs the web site http://www.mycelium-fr. com and has curated a Summer exhibition entitled Mycelium - Génie savant, génie brut, in Auberive (Haute-Marne) from June till September 2014.

Among his major publications are:

Artaud et l'asile (with A. Roumieux), Paris, 2015; Aux Frontières de l'art brut - Un parcours dans l'art des marges,Paris, 2013; Le dessin à l'ère des nouveaux médias,Paris, 2009; Pour un art postcontemporain, Paris, 2008; Art brut - L'instinct créateur, Paris; 2006.; Jean Dubuffet, peintre philosophe, Paris, 2001.

Carole Tansella, Section Editor 